\title{
IgG Monoclonal Gammopathy
}

National Cancer Institute

\section{Source}

National Cancer Institute. Ig G Monoclonal Gammopathy. NCI Thesaurus. Code C128810.

An abnormal laboratory test result indicating the presence of IgG monoclonal

immunog lobulin in the blood or urine. 